\title{
Ground Water Lowering and its Adverse Effect on Agriculture in some Productive Villages of Paschim Medinipur District of West Bengal
}

\author{
Pragna Bhattacharya
}

Y.S Palpara Mahavidyalaya, Palpara, Purba Medinipur, West Bengal, India

Corresponding author: pragna_moon@yahoo.co.in

\begin{abstract}
Ground water is an important source of water supply throughout the world. Its use in irrigation, industries and households continues to increase. Storage of ground water is to be estimated accurately and proper planning is required to ensure continued availability of water supply. Some parts of my study area that is under Daspur I block in the district of Paschim Medinipur of West Bengal registered comparatively low ground water level and which has started to create problems in agricultural activity in these productive land areas especially in pre-monsoon period. So here a study has been made on the six villages of Basudebpur Gram Panchayet of Daspur I block, characterized with comparatively low ground water level. Various uses of ground water have been discussed here. The environmental influence on ground water has been analysed based on meteorological information (Temperature and rainfall data) and secular, seasonal and short term variations of ground water are also been discussed over the study villages. A comparative study is made between present ground water level and the irrigated area of the study area over five years. And finally some methods regarding ground water recharge like artificial recharge method (Ditch and furrow method, Irrigation method, Pit Method) have been suggested for the replenishment of the ground water in the study area which will give a positive impact on agriculture in these study villages.
\end{abstract}

Keywords: Ground water lowering, irrigation, agriculture, productivity, porosity, ground water recharge methods

Ground water exploitation is a major concern in the world at present. This results the steep decline of water table in many areas. Extraction of ground water due to many purposes is causing the shortage of ground water. Storage of ground water is to be estimated accurately and need proper planning (Johnston, R.J. 1985). Ground water is the only source of water in some parts of rural villages of Paschim Medinipur. Some parts of Daspur I block in the district of Paschim Medinipur registered low ground water level compared to the other parts of the district. Being situated in the productive alluvial track, the agricultural activity in these areas has been interrupted especially in pre-monsoon period because of the lowering of the ground water. So here a study has been made on six sample villages of Basudebpur Gram Panchayet of Daspur I block, characterized with comparatively low ground water and $t$ which is causing adverse effect on agriculture Objectives: The objectives of the study is grouped into following:

1. Firstly to study the status and utilization of ground water level in the study area.

2. To analyse the relationship between environmental influence and ground water level.

3. To make a comparative study between present ground water level and the irrigated area of the study area over five years.

4. Finally to suggest rational plans to manage the situation. 


\section{MATERIALS AND METHODS}

First of all lots of literature surveys are done based on ground water hydrology. In Daspur- I block six mauzas [Barasimulia (62), Basudebpur (62), Baikunthapur (64), Kalmijor (65), Khatbaui (66), and Radhakantapur (67)] were selected as sample villages. For each mauza, ground water level have been measured at different interval. Various uses of ground water in the study area collected from household survey and the environmental influence on ground water has also been studied based on meteorological information for both in monsoon and pre monsoon period. A comparison is made on the present ground water level and the agricultural scenario of the study area. Here two parameters are taken for the comparative analysis. One is the ground water level in pre-monsoon period in 200102 and 2006-07 and another is irrigated area in those years in the study villages. The analysis shows that the irrigated area is changing with the use of ground water and more use of ground water for irrigation is resulting the lowering of the level of ground water. And finally some methods relating to ground water recharge like artificial recharge method (Ditch and furrow method, Irrigation method, Pit Method) have been studied and suggestions are made for the replenishment of the ground water in the study area. Data are collected from two sources i.e. primary sources and secondary sources. Primary data are collected from door to door survey, measuring of surface water and ground water level at different times of the year along with temperature and pressure. Whereas secondary data are collected from the following offices like D.L.L.R.O (District Land and Land Reform Office), Water investigation and Development Office etc.

Extensive study regarding ground water hydrology, lowering of ground water, recharge of underground aquifer over the space had been done for the case study. A review of existing literature (Kothari, 1990) is given here. The concept of infiltration and ground water recharge was given by W.O Smith in his book entitled as, Infiltration in sands and its relation to ground water recharge; water Resources Research, published in 1967. Application of engineering in ground water management was discussed by the Civil Engineer Amer, Soc Ground water management, Manual Engineering Practice published in 1972. Details about ground water hydrology were discussed by D. K. Todd in his famous book "Ground water Hydrology" which is published in 2006 in second edition. The concept of recharge of ground water was given by A.H. Johnson in his book "Ground water recharge on Long Island" published in 1948.

\section{RESULTS AND DISCUSSION}

In Paschim Medinipur District, in Ghatal sub division, some villages are registered with low ground water level. Out of these villages the six villages are selected for sample villages. These are Barasimulia (62), Basudebpur (62), Baikunthapur (64), Kalmijor (65), Khatbaui (66), and Radhakantapur (67) which are situated in Daspur I block. Ground water potential of the study area is more than 40 yield in litre/sec here. The area is under primary inter - granular porosity. Average ground water level of these villages are:

Table 1: Table showing pre-monsoon and post monsoon condition of ground water level in the selected villages

\begin{tabular}{ccc}
\hline Name of villages & $\begin{array}{c}\text { Pre-monsoon } \\
\text { cond (mbgl) }\end{array}$ & $\begin{array}{c}\text { Post-monsoon } \\
\text { cond (mbgl) }\end{array}$ \\
\hline Barasimulia (62) & 14.9 & 5.02 \\
Basudebpur (63) & 15.01 & 4.99 \\
Baikunthapur (64) & 14.5 & 4.87 \\
Kalmijor (65) & 14.32 & 5.56 \\
Khatbarui(66) & 14.77 & 5.78 \\
Radhakantapur (67) & 14.92 & 5.33 \\
\hline
\end{tabular}

Source: Primary data and Gram Panchayet.

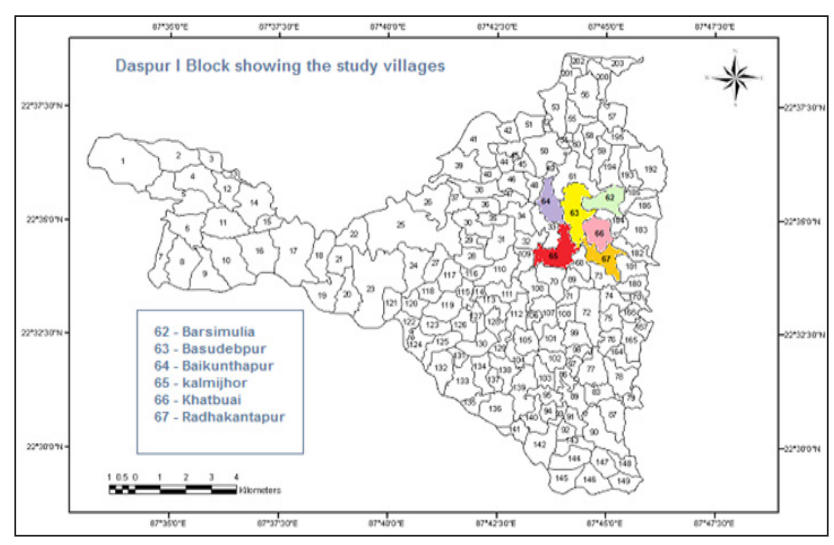

Fig. 1. Location Map of the study area

\section{Utilization of ground water in the area}

Ground water is widely utilized in the rural part of the Paschim Medinipur district. Still here 
agricultural and domestic activity mainly depends upon ground water. In the study area ground water is utilized in various activities such as for rural domestic works, rural livestock, irrigation, tube well, public water supply etc. The graphs are (Fig. 2 and 3) showing that in the study area out of total water use $65 \%$ is ground water and only $35 \%$ is surface water. Out of $65 \%$ water use highest percentage of water used in irrigation, it is $30 \%$. Public water supply included tube well and tap registered $22 \%$. Whereas rural domestic and livestock indicates $11 \%$ and $2 \%$ respectively (the information is collected from on local survey and Gram Panchayet Office).

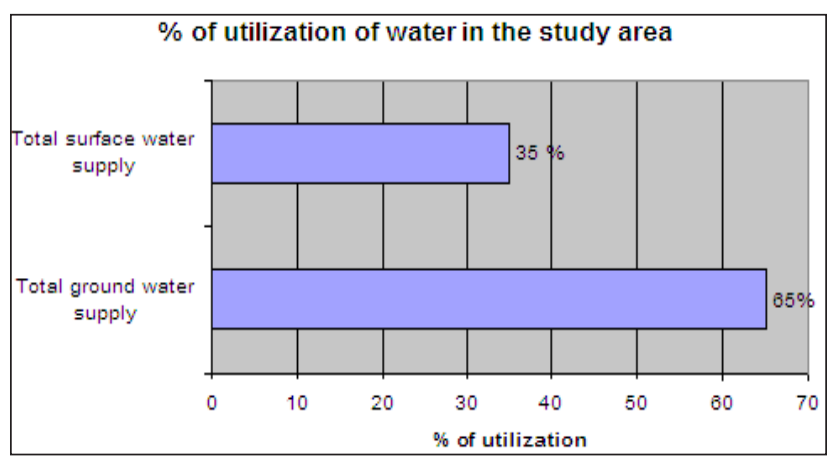

Fig. 2: Utilization of ground water in the study area

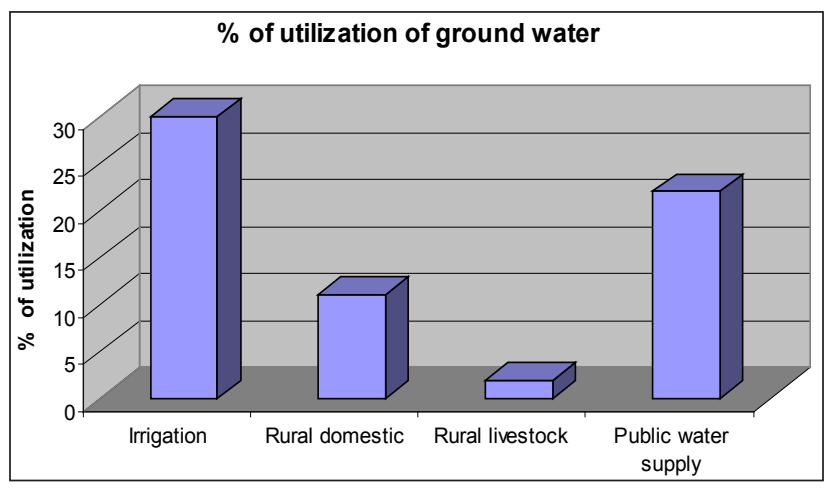

Fig. 3: Percentage of ground water use to total water use in the study area

\section{Causes of Lowering of Ground water}

In the study villages agricultural activities are based on irrigation and where maximum ground water is utilized. Though there little amount of water is supplied from Govt canal (surface water), but major thrust is given on ground water based irrigation and various sources of irrigation are MDTW (Medium Capacity Deep Tube Well), HDTW (High Capacity Deep Tube Well), STW (Shallow Tube Well) and which are accelerating the rate of ground water lowering in the study area. Besides this geologic formation of the study area is also responsible to some extent for the lowering of ground water level. A geologic formation which yields significant quantities of water is defined as aquifer (Todd, 2006). A key requirement of the aquifer is to store water in the rock pores. Porosity may be derived from inter-granular spaces and from fracture. In the study are three types of soil have been found which are sandy loam, loam and clay loam. This is the textural classification. Geologically this soil is characterized with unconsolidated sedimentary layer. And in clay loam soil porosity is comparatively low. In the study area most of the area is covered by clay loam type of soil. Representative values of porosity after Morris and Johnson had shown less porosity in the clay soil. So here the porosity is also very low. This hinders free percolation and infiltration and natural recharge of ground water table. So all these factors are responsible for the lowering of the ground water in these study villages.

\section{Ground water level and environmental influence}

Level of ground water is influenced by various environmental causes. It may be meteorological causes and other adverse causes such as tidal phenomena, urbanization, earth quake, subsidence of land surface and any other external loads etc. Especially differences between supply and withdrawal of ground water results in ground water fluctuation (K.P Singh, 1998). Among meteorological causes seasonal variation (temperature and rainfall), change of atmospheric pressure cause ground water fluctuation.

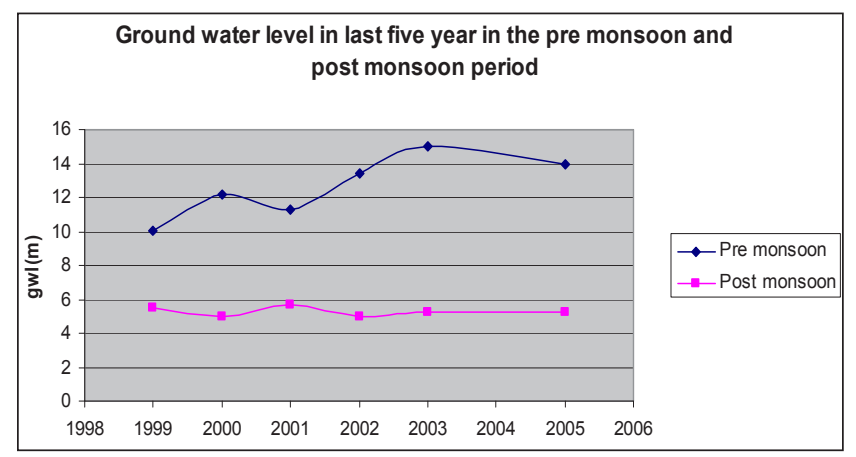

Fig. 4: Ground water level in pre-monsoon and post monsoon period

So in the study area the influence of environment on ground water have been studied in details. Three 
types of variation of ground water level have been studied in the sample villages. The variations are secular variation, seasonal variation, and short term variation (Todd, 2006).

\section{Secular variation}

Secular variation of ground water levels are those extending over several years or more. Here relationship has been shown on average ground water level and mean temperature of the study area of last five years. The graph is showing the lowering of ground water is increasing from 1998. In 2001, it shows little decreasing tendency and after 2001 the graph is showing increasing tendency in pre-monsoon period. In post monsoon period the level of ground water shows a steady state. The maximum temperature graph has a positive relation with the pre-monsoon ground water level graph. Both are showing increasing tendency in most of the years.

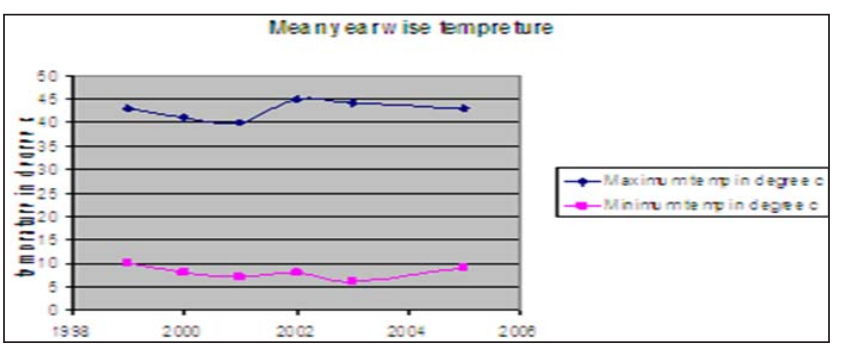

Fig. 5: Mean year wise temperature

\section{Seasonal variation}

Seasonal variation simply means variation within a year. In the 2002-03 seasonal variation has been shown. The variation is mainly due to rainfall fluctuation and irrigation pumping. The seasonal variation is showing maximum lowering in the month of April and then in January. Mainly because in these months rainfall in very minimum and withdrawal is high for irrigation. Comparatively in November and August water level is much higher (Fig. 6).

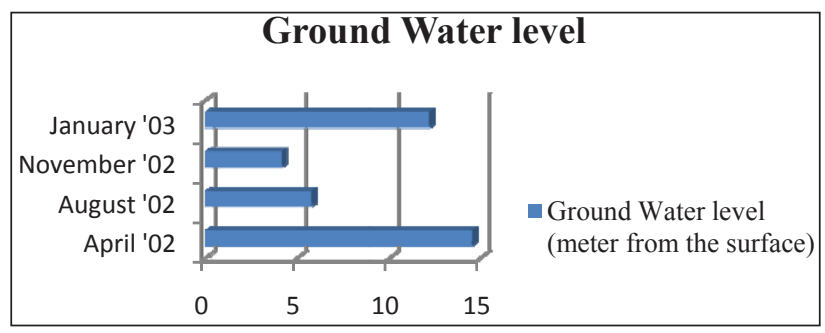

Fig. 6: Ground water level in different seasons

\section{Short term variation}

Short term variation mainly indicates diurnal variation. This is governed by the primarily use of the ground water in a locality. The difference between ground water level in day time and evening is higher in pre-monsoon period than post monsoon period. In the study areas the variation of ground water level shows higher value in premonsoon than the post monsoons period, which proves the maximum dependency of ground water in per monsoon period.

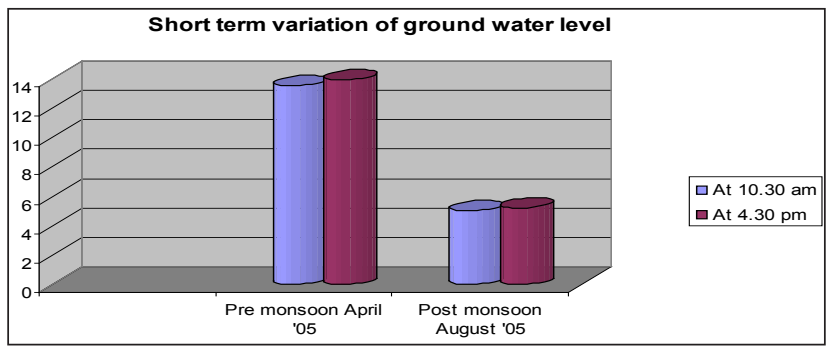

Fig. 7: Ground water level based on short term variation

\section{DISCUSSION}

\section{Ground water level and agriculture}

The study area is under alluvial track and that is why agriculture is the primary activity of the rural people of the study area. Here for agriculture both surface and sub-surface water is used but dependency on ground water is much higher especially in the winter and dry season. In winter boro cultivation is done, which is completely irrigation based (Paschim Banga, Medinipur Sankhya 2008). Irrigation completely depends on ground water and that is one of the main cause of ground water lowering. In recent years cropping intensity of the area has decreased. In 2006, the cropping intensity (Husain, M 1995) of Daspur I block was 270.7 and in 2008 it become 263.90 . The lowering of ground water level is reducing the cropping intensity in the study villages. The cropping pattern of the Daspur I block comprised of Amon paddy (43\%), Aus paddy (25\%), potato ( $8 \%$ ), and vegetables $(7 \%)$ in $2007-08$. The table shows (Table 2) the total geographical area and the total irrigated area of the of the villages in 2001. But in 2007-08 the scenario has quite changed. Especially in Basudebpur, Baikunthapur, Barsimula and Radhakantapur total irrigated area has increased 
and almost entire area is brought under irrigation facility. In most of the sample villages the sources of irrigation are well and tube well. In the Barsimula, Basudebpur and Radhakantapur along with well and tube well little canal irrigation is also continued and in Kalmijor most of the area is under river irrigation. So it is clear that well and tube well irrigation is the main sources of irrigation in the study area and this is responsible for the lowering of ground water level in the study area.

Table 2: Table is showing total area and total irrigated area of the selected villages

\begin{tabular}{ccc}
\hline Name of villages & Total area (hec) & $\begin{array}{c}\text { Total irrigated area } \\
\text { (2001) (hec) }\end{array}$ \\
\hline Barasimulia (62) & 134.63 & 74.40 \\
Basudebpur (63) & 205.18 & 84.16 \\
Baikunthapur (64) & 119.14 & 63.97 \\
Kalmijor (65) & 175.58 & 99.95 \\
Khatbuai (66) & 126.14 & 71.70 \\
Radhakantapur (67) & 131.29 & 67.33 \\
\hline
\end{tabular}

\section{Relation between ground water level and total irrigated area}

The graphs are showing the relationship between ground water level in pre-monsoon period and total irrigated area in the year of 2000-01 and 2006-07. From the graphs it is clear that the total irrigated area in the villages of Barsimula, Basudebpur, Baikunthapur and Radhakanthapur have increased from 2000-01 to 2006-07 and the depths of ground water level from the surface in those villages been lowered from 2000-01 to 2006-07.

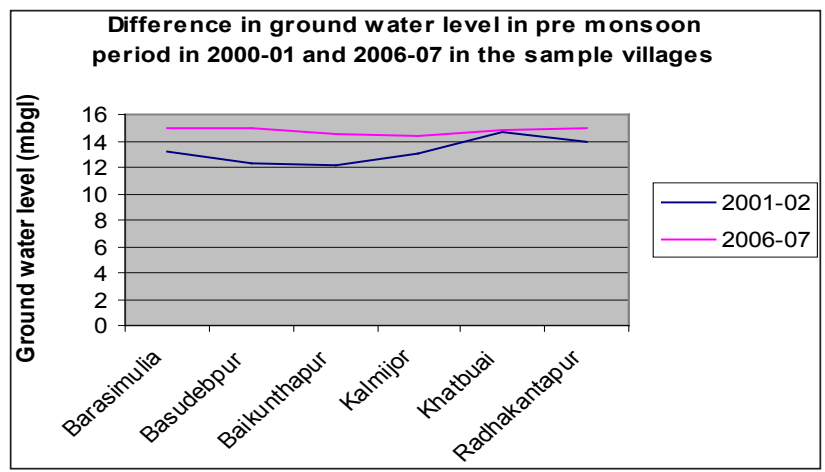

Fig. 8: Difference in ground water level in pre monsoon period in 2000-01 and 2006-07

In those villages the sources of irrigation are MDTW and HDTW. In the villages like Kalmijhor and Khatbuai the changes of ground water level and the total irrigated area is very limited from 2000-01 to 2006-07 as in Kalmijhor and Khatbuai the irrigation is not ground water dependent. In those villages the agricultural activity is done mainly by river and canal irrigation. So it is clear from the above discussion that lowering of ground water level is very much influenced by the irrigation practice in the study areas.

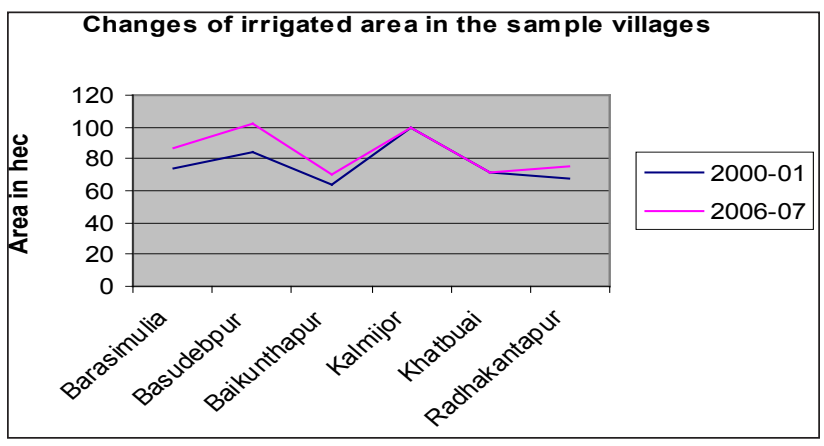

Fig. 9: Changes of irrigated area in the sample villages

\section{Suggestions}

\section{(I) Ground water investigation}

A thorough ground water resource assessment is required for preparing a management plan. Following steps are to be followed for investigating ground water resource potential and preparing management proposal. Withdrawal amount has to be monitored and restriction has to be imposed to maintain a balance between recharge and withdrawal.

\section{(II) Artificial recharge method}

Artificial recharge method can be applied in the study area, where ground water level is comparatively low. Artificial recharge method (Johnston, 1948) may be defined as augmenting the natural movement of surface water into underground formation by some method of construction, by spreading of water, recharging through pits and wells or by artificially changing natural conditions. Artificially recharge method are designed to serve one or more purposes:

(i) Maintain natural ground water as an economic resource.

(ii) Coordinate operation of surface and groundwater reservoirs.

(iii) Combat adverse condition like progressive lowering of ground water condition. 
(iv) Provide sub surface storage for local or imported surface water.

(v) Reduce or stop significant land subsidence.

The methods can be applied in the study area are:

(a) Ditch and furrow method - In this method water is distributed to a series of ditches and furrows that are shallow, flat bottomed and closed spaced to obtain maximum water contact area. One of three basic layouts is generally employed: Following contour, tree shaped layout and lateral layout. Ditch widths ranges from 0.3 to $1.8 \mathrm{~cm}$.

(b) Irrigation method - In irrigated areas water is sometimes deliberately spread by irrigating cropland with excess water during nonirrigating seasons. The methods require no additional cost for land preparation because the distribution system is already installed (Wilcox, 1055). Where a large portion of water supply is pumped, the method has the advantage of rising water table and consequently reducing power costs.

(c) Pit Method - A pit excavated into a permeable formation serves as an ideal facility for groundwater recharge. It is most economic. The steep sides provide high silt tolerance. Silt usually settled down the bottom leaving the wall relatively unclogged for continued infiltration of water. The pits are 9 to $7 \mathrm{~cm}$ depths.

Rain water harvesting: It is a process where rain water is stored in the reservoir or any water storage tank. By this seasonal rain water is stored and this can be utilized in agriculture and other activities. This reservoir and storage help water to infiltrate and recharge ground water.

So, these are the process by which ground water can be recharged and this process can be implemented in the study region. Rational use of both ground and surface water is very much essential for keeping the water balance in the study region.

\section{CONCLUSION}

The study area is situated in the comparatively low ground water zone in the district of Paschim Medinipur. In the study area the land is very much productive. Here hundred percent soil is alluvial type, and agriculture is mainly dependent on ground water, causing lowering of ground water. So limited use of ground water is very much essential in the study area. Here some methods can be applied to replenish the ground water level. Artificial recharge methods and rain water harvesting are to be followed. For the availability of ground water these methods should be physically feasible and most economical in this fertile area. Overall continuous monitoring of ground water resource and its use are to be done and rational management plan has prepared to stop lowering of ground water to ensure its supply in long run.

\section{REFERENCES}

Amer, Soc. Civil Engrs, Ground water management, Manual Engineering Practice, 1972, New York, pp. 216.

Husain, M. 1995. Agricultural Geography, Rawat Publication, pp. 213-272.

Johnson, A.H. 1948. Ground water recharge on Long Island, Jour, Amer. Water Works Assoc., 40: 1159-1166.

Johnston, R.J. 1985. The Dictionary of Human Geography, Basil Blackwell stel.

Kothari C.R. 1990. Research Methodology, Methods and Techniques, Second ed. Wiley Eastern, New Delhi.

Paschimbanga, Medinipur Sankhya 2008.

Singh, K.P. 1998. Some factors affecting base flow, Water Resources Research, 4: 485-999.

Smith, W.O. 1967. Infiltration in sands and its relation to ground water recharge, Water Resources Research, 3: 539 555.

Todd, D.K. 2006. Ground water Hydrology, $2^{\text {nd }}$ Ed, Wiley Student Edition.

Wilcox, L.V. 1995. Classification and use of irrigation water, U.S Dept. of Agric, Circ, 969, Washington. D.C. pp. 19. 